\title{
The Culture of Extracting Information through Politeness Strategy on Mata Najwa Television Program
}

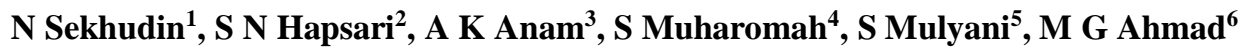 \\ Universitas Indraprasta PGRI, Jakarta, Indonesia \\ nur.sekhudin@unindra.ac.id
}

\begin{abstract}
Information extraction through talk show by various broadcast stations has become culture itself. A significant increase of similar format with slightly different styles were produced by various broadcast stations as if it is a competition. There are known as if these talk shows are a culture viewed as an art of obtaining information through questions and statements in verbal circumstance which make politeness strategy as a compulsion. The study has presented the use of politeness strategy in Mata Najwa television program Episode "Mendadak Capres" which based the politeness strategy from Brown and Levinson. The data is taken from Mata Najwa television program episode "Mendadak Capres" in which the use of politeness strategy will be analyzed. The result showed the use of positive politeness strategy is much more prevalent than the use of bald on record strategy.
\end{abstract}

Keywords: Talk Show, Tv Program, Politeness Strategy, Mata Najwa, Positive Politeness

\section{INTRODUCTION}

Language use is a way to communicate between peoples within community. The longevity of a language is strongly influenced by the occurring dynamic and the dynamic within the speaker itself, that is the language society. Many experts have stated theories regarding the relationship between language and culture, the expert which is Sapir have said as quoted "Human beings do not live in the objective world alone, nor alone in the world of social activity as ordinarily understood, but are very much at the mercy of the particular language which has become the medium of expression for their society. It is quite an illusion to imagine that one adjusts to reality essentially without the use of language and that language is merely an incidental means of solving specific problems of communication or reflection. The fact of the matter is that the 'real world' is to a large extent unconsciously built upon the language habits of the group. No two languages are ever sufficiently similar to be considered as representing the same social reality. The worlds in which different societies live are distinct worlds, not merely the same world with different labels attached. We see and hear and otherwise experience very largely as we do because the language habits of our community predispose certain choices of interpretation"[1].

"To say that two people belong to the same culture is to say that they interpret the world in roughly similar ways and can express themselves, their thoughts and feeling about the world, in ways which will be understood by each other"[2]. Based on the statement above, language politeness is a reflection of the characters and the personality of speaker as culture embodiment 
that belong to them. Moreover, language used in communication within community members need to pay attention closely on language rule includes linguistic rule and non linguistic in order to achieve an effective communication. This shows language function is not only to communicate but also to display the social identity of the speaker as well as their culture. Therefore, politeness is strongly attached to cultural norms of the speaker and listener in a communication. The culture of everyday life includes the whole complex of human relations: the culture of communication and behavior, the culture of mass media communication and the culture of life styles. In linguistic terms, the category of everyday life presents a system of all processes of language functioning, all forms and types of communication, manifested in forms of individual or collective discourses [3]. Moreover, Indonesian TV shows often shows talk show program as tool in order to obtain information which correlates with language use especially Bahasa Indonesia as communication tool.

Deutschman states the form of politeness is not universal but it formed by social backgrounds as the form and the background could not be separated. He added three things that determine the form of politeness people adopt, there are cultural norms, circumstances, and characteristic of the message [4]. This showed language behavior of someone could be seen on language norms appreciation. In other words, language politeness is the rule or norm of language behavior that need to be agreed upon by community members to manage and maintain social and psychological relationship of the speakers.

Thought associated with the relativity of language is known as the Sapir Whorf hypothesis which states that language determines the worldview of a speaker through its grammatical categories and semantic classifications. There is a weak version and a strong version of the hypothesis which are related to the relativity of language. The stronger version supports the Sapir-Whorf hypothesis that language "determines" the speaker's worldview, while the weak version believes that language only "affects" the speakers' worldview. Related to the idea of language as energies, something that is alive and affects the perspective of the speakers, we'll look at what is happening in the language behaviour of the Indonesia people today [5].

TV broadcasting has showed its rapid development in recent years. Many TV stations are present in the middle of community. Variety of contents are presented by each TV stations in Indonesia. One of interesting show that worth to be studied is talk show program which presents dialog in a question and answer format. Questions and statements utterences in comunication process should be selected carefully whether based on the broadcast ettique or by the language structure (norm). Mata Najwa television program is very interesting to study. The conversation between Najwa the host and the guests invited to the show is very intriguing due to its question and answer format. Questions that Najwa asked towards the guests sometimes is categorized into politeness theory so at times it makes the guests lost their face as individual, therefore the guest and the host as participants of communication process could use a proper language politness strategy. Brown and Levinson (1987), state that in performing face threatening acts striking consideration must be employed to pick out the most direct and efficient face threatening act on record and to mitigate the upshot of face threatening act (FTA) on the hearers' side (off- record) [6]. Mata Najwa television program will be our study focus using the politeness theory. Using language as media to extract information delivered to the guests must have strategy supposed to make the language of the speaker does not sound offensive for their speaking partner. However, in reality Najwa Sihab as the host does sounds offensive towards her guests (talking partner). The aims of study is to find out language politness as culture of information extraction used by the host and the guests of Mata Najwa television program episode "Mendadak Capres" 


\section{METHOD}

This study aimed to describe the phenomena of using politeness strategies in Mata Najwa television program Episode "Mendadak Capres" at 29 November 2012. This present research used qualitative approach qualitative approach is applied in order to conduct the presented study. According to Crasswell as cited by Asri Dwi E.S, qualitative approach concern on the natural phenomena. The researcher becomes the main instrument of data collection that compiles the words, analyze the data inductively, concern with the meaning of participants and describe an expressive language process [7].

To implement this study, the data is collected by watching the main data sources which is Mata Najwa television program and its transcription of the dialogues taken from numbering the utterances. Then, the utterances will be classified based on the form, the producer and the type of Brown and Levinson's politeness strategy. The extracts of dialogue in this research are compiled from the conversation between Najwa Shihab as the host of Mata Najwa television program and Rhoma Irama as the guest . The extract dialogue in this episode has 128 utterances in total. The extract of dialogue will be divided into 16 propositions of utterance pairs then proceeds to do the analysis. The analytical framework of the study is based on Brown and Levinson (1987).

\section{RESULT AND DISCUSSION}

Brown and Levinson introduce the notion of 'face' in order to illustrate 'politeness' in the broad sense. That is to say, all interactants have an interest in maintaining two types of 'face' during interaction: 'positive face' and 'negative face'. Brown and Levinson define 'positive face' as the positive and consistent image people have of themselves, and their desire for approval. On the other hand, 'negative face' is "the basic claim to territories, personal preserves, and rights to non-distraction". Utilising this notion of 'face', 'politeness' is regarded as having a dual nature: 'positive politenesses and 'negative politenesses. 'Positive politeness' is expressed by satisfying 'positive face' in two ways: 1) by indicating similarities amongst interactants; or 2) by expressing an appreciation of the interlocutor's self-image. 'Negative politeness' can also be expressed in two ways: 1) by saving the interlocutor's 'face' (either 'negative' or 'positive') by mitigating face threatening acts (hereafter FTAs), such as advice-giving and disapproval; or 2) by satisfying 'negative face' by indicating respect for the addressee's right not to be imposed on. In short, 'politeness' is expressed not only to minimize FTAs, but also to satisfy the interactants' face regardless of whether an FTA occurs or not [8].

Based on the analyses results of politeness strategies in Mata Najwa television program Episode "Mendadak Capres" using type of Brown and Levinson politeness strategy from 16 proposition utterance pairs. Around $88 \%$ proposition utterance pairs using positive politeness strategy, which shows an exaggeration on interest, agreements, and sympathy towards speaking partner. Thus, communication participants shows effort to communicate while minimize the menace of losing face. Moreover, communication happens in Mata Najwa television program episode "Mendadak Capres" did not applied bald on record strategy. However, some politeness strategy were used together in one utterance pairs proposition there are utterance pairs five, six, eight, twelve, and fifteen which they both uses positive politeness strategy and off record strategy at the same time and in one utterance pairs proposition. The study on politness have been done by many researcher including Akutsu Yuka (2009), Hamidreza Dowlatabadi et.al (2014), Marina Ryabova (2015), Karimkhanlooei \& N. Vaezi (2017) and many others. 
Similar study that had ben conducted by Hamidreza Dowlatabadi et al (2014) have relevant discussion with this study which focused on on the socio-cultural aspects of conversation, the present study focuses on politeness strategies in conversation exchanges in the Council for dispute settlement in Esfahan, Iran. This study attempts to find out what strategies are more frequently used by Iranian interlocutors in the context of dispute settlement. For analyzing the data, the model of politeness strategies proposed by Brown and Levinson (1987) was employed. It was found that the strategies of "Notice, attend to H", "Seek agreement", and "Avoid disagreement" were most frequently used. For the example The last and the most frequent strategy identified in this study is the strategy of "Avoiding disagreement". This seems similar to the previous strategy of seeking agreement, but surely there are areas of difference. Here, the context of the discourse is threatening, that is the context pushes the participants toward disagreement, but the participants try to avoid such disagreement to settle their dispute. Of course, even an utterance regarding disagreement triggers the participants to avoid the situation. This is mostly realized through extreme adjectives like "absolutely, surely, certainly, never, always". There are four categories for this strategy:

Token agreement: the desire to agree or appear to agree with $\mathrm{H}$ leads to mechanisms for pretending to agree.

Pseudo-agreement: an example of apparent or pseudo-agreement is in the use of then and so in English as conclusory markers.

White lies: in order to avoid damaging the H's positive face, the $\mathrm{S}$ when confronted with the necessity to state an opinion, wants to lie.

Hedging opinion: $\mathrm{S}$ may choose to be vague about his own opinion, so as not to be seen to disagree. This is manifested by choosing words such as: sort of, in a way (Brown and Levinson, 1987:113). The following extract, focuses on the first sub-strategy of avoiding disagreement. Here, the participants are using token agreement to pretend their avoidance of disagreement with what the judge is uttering. The judge is stating some facts about the law, the response of which from the man's side is to affirm such utterances. When the judge says "You see, when a property is mortgaged by the bank, it means that the bank owns it. It's not yours anymore", the man's affirm with a "right". But the most prominent example of token agreement is the usage of extreme adjective of "absolutely" by the man after judge's uttering "all your belongings are for your wife". This is to jump into the same ground with the judiciary power, passing the situation through pretending to be in agreement. Of course, when the wife's claims his dowry in the court of law, it is not very pleasing to the man, though it is her right to claim, but the affirmation of the judge's utterance is just a pretence to be cooperative and polite in the course of conversation [9].

Based on the perspective of the theroy used in Downlata study is indeed similar with this one. However, intruments used in Downlata stude only emphasize on the positive language politness strategy while the object of the study is far different even though the goals is to find out the langauge politness strategy use in extracting infromation. A more narrowed study was conduscted by Akutsu Yuka (2009) on positive language politness strategy in descriptive and analysis details of addressing term in high school textbook approved by Japanese Ministry of Education, Culture, Sports, Science and Technology that is Oral Communication I textbooks. The focus of this paper are to find out the amount and the kind of addressing terms presented, which is one of the important positive politeness strategies [10].

\section{CONCLUSION}

The analysis result of language politeness strategy in Mata Najwa television program Episode "Mendadak Capres" concludes 14 out of 16 utterance pairs preposition of politeness 
strategy in Mata Najwa which showed the dominant of positive politeness strategy with $88 \%$ while off record strategy used in only 5 utterance pair preposition with $31 \%$, and the other 3 utterance pair preposition used negative politeness strategy with $19 \%$. However, from the percentage found in the study showed some politeness strategy were used together in one utterance pair preposition, there are utterance pairs five, six, eight, twelve, and fifteen which they both uses positive politeness strategy and off record strategy at the same time and in one utterance pairs proposition.

\section{REFERENCES}

[1] D. Lawton, "Language and Culture," Sociology, vol. 2, no. 2, pp. 254-255, May 1968.

[2] S. Hall, Ed., Representation: Cultural representations and signifying practices. London: Sage Publication, 1997.

[3] M. Ryabova, "Politeness Strategy in Everyday Communication," Procedia - Soc. Behav. Sci., vol. 206, no. November, pp. 90-95, Oct. 2015.

[4] M. Deutschmann, "Apologising in British English,” Skr. från Mod. språk, vol. 34, p. 262, 2003.

[5] S. Darmojuwono, "Language, culture, and social cognition," Wacana, vol. 17, no. 1, pp. 121-133, 2016.

[6] G. Karimkhanlooei and N. Vaezi, "Politeness strategies in written communications: the issue of Iranian EFL learners," J. Lang. Cult. Educ., vol. 5, no. 3, pp. 108-126, Sep. 2017.

[7] W. Waliyadin, "The Impoliteness in The Charlie Pippin: a Pragmatic Study," Vis. J. Lang. Foreign Lang. Learn., vol. 5, no. 2, p. 93, Oct. 2016.

[8] H. Kawamura, K. Hayakawa, N. Nomiya, and R. Sugita, "Effect of interlayer interaction on domain structure of CoPt stacked films with perpendicular anisotropy," J. Appl. Phys., vol. 117, no. 17, p. 17B501, May 2015.

[9] H. Dowlatabadi, E. Mehri, and A. Tajabadi, "Politeness Strategies in Conversation Exchange: The Case of Council for Dispute Settlement in Iran," Procedia - Soc. Behav. Sci., vol. 98, no. May, pp. 411-419, 2014.

[10] Y. Akutsu, "Exploring meta-pragmatic awareness of Japanese learners of English: Focusing on speech act of request by lower-intermediate proficiency college students," Econ. J. Tak. City Univ. Econ., vol. 54, no. 4, pp. 121-134, 2012. 